\title{
Nanoscale
}

\section{Accelerating peroxidase mimicking nanozymes using DNA}

Received 00th January 20xx,

\author{
Biwu Liu and Juewen Liu*
}

Accepted 00th January 20xx

DOI: $10.1039 / x 0 \times x 00000 x$

www.rsc.org/

DNA-capped iron oxide nanoparticles are nearly 10 -fold more active as a peroxidase mimic for TMB oxidation compared to the naked nanoparticles. To understand the mechanism, the effect of DNA length and sequence is systematically studied, and other types of polymers are also compared. This rate enhancement is more obvious with longer DNA and in particular, poly-cytosine. Among the various polymer coatings tested, DNA offers the highest rate enhancement. Similar acceleration is also observed with nanoceria. On the other hand, when the positively charged TMB substrate is replaced by the negatively charged ABTS, DNA inhibits oxidation. Therefore, the negatively charged phosphate backbone and bases of DNA can increase TMB binding by the iron oxide nanoparticles and thus facilitating the oxidation reaction in the presence of hydrogen peroxide.

Nanomaterials as enzyme mimics (nanozymes) have received considerable attention recently. ${ }^{1-3} \mathrm{~A}$ wide range of nanomaterials including gold nanoparticles, ${ }^{4,5}$ metal oxides, ${ }^{6-9}$ and carbon-based materials ${ }^{10}, 11$ have been reported to have oxidase, peroxidase, catalase, and superoxide dismutase like activity. Among these nanozymes, iron oxide nanoparticles (e.g. $\mathrm{Fe}_{3} \mathrm{O}_{4}$ NPs) are particularly interesting because of their unique magnetic properties and applications in magnetic resonance imaging, drug delivery, and separation. ${ }^{2}$ Based on the peroxidase activity of $\mathrm{Fe}_{3} \mathrm{O}_{4}$ NPs, colorimetric biosensors for $\mathrm{H}_{2} \mathrm{O}_{2}$ detection have been developed using chromogenic substrates (e.g. 3,3',5,5'-tetramethylbenzidine (TMB), and 2,2'-azino-bis(3-ethylbenzothiazoline-6-sulfonic acid) (ABTS)). ${ }^{12}$ When glucose oxidase is combined with $\mathrm{Fe}_{3} \mathrm{O}_{4}$ NPs, glucose can also be selectively detected..$^{13}$ For practical applications and fundamental mechanistic understanding, factors affecting the peroxidase activity need to be fully addressed. ${ }^{14-17}$ For example, the surface $\mathrm{Fe}^{2+}$ content was found to be vital in its oxidation activity. ${ }^{6}$ Prussian blue modified $y-\mathrm{Fe}_{2} \mathrm{O}_{3}$ NPs have an elevated surface $\mathrm{Fe}^{2+}$

Department of Chemistry, Waterloo Institute for Nanotechnology,

University of Waterloo, Waterloo, Ontario, N2L 3G1, Canada

E-mail: liujw@uwaterloo.ca; Fax: +1 519746 0435; Tel: +1 5198884567 ext. 38919

†.Electronic Supplementary Information (ESI) available: Methods, TEM, UV-vis and DLS data. See DOI: 10.1039/x0xx00000x content and thus a higher enzymatic activity. ${ }^{15}$ Also, the role of surface charge on substrate oxidation was investigated and electrostatic interaction was found to be crucial for substrate binding. ${ }^{14}$ The activity of unmodified NPs is often quite low, and an important challenge in this field is to promote their catalytic activity. We reason this goal might be achieved via understanding the surface chemistry of the reactions.

DNA-functionalized NPs represent an important hybrid material in bionanotechnology. ${ }^{18-21}$ Since the seminal work by the Mirkin and Alivisatos groups, ${ }^{22,23}$ a plethora of DNA-NP conjugates have been reported for various applications, such as directed assembly of nanostructures, ${ }^{24-26}$ biosensing, ${ }^{27-30}$ and drug delivery. ${ }^{31}$ DNA functionalization not only improves the colloidal stability of NPs, but also provides additional molecular recognition ability (e.g. aptamers) toward metal ions, small molecules and proteins. ${ }^{29,32,33}$ DNA-functionalized $\mathrm{Fe}_{3} \mathrm{O}_{4}$ NPs have been successfully used for detecting arsenate ions, ${ }^{34}$ and biomolecules. ${ }^{35}$ However, the effect of DNA modification on the intrinsic properties of $\mathrm{Fe}_{3} \mathrm{O}_{4} \mathrm{NPs}$ is less explored. Herein, we communicate that DNA-modified $\mathrm{Fe}_{3} \mathrm{O}_{4} \mathrm{NPS}$ exhibit significantly enhanced peroxidase activity for TMB oxidation compared the bare NPs. Further studies show that both surface charge and DNA base composition are important for modulating the substrate affinity to $\mathrm{Fe}_{3} \mathrm{O}_{4} \mathrm{NPs}$, and thus the catalytic activity.

Peroxidases catalyse substrate oxidation in the presence of hydrogen peroxide. $\mathrm{Fe}_{3} \mathrm{O}_{4}$ NPs were first reported to have peroxidase activity in 2007. ${ }^{6}$ We characterized our $\mathrm{Fe}_{3} \mathrm{O}_{4} \mathrm{NPs}$ using TEM (Figure S1). The NPs are spherical and have a size range from $20 \mathrm{~nm}$ to $50 \mathrm{~nm}$. Slight aggregation was observed attributable to the unmodified surface. We are interested in studying naked NPs without strong capping ligands, so that the surface property can be better controlled. No obvious light absorption features were observed using UV-vis spectroscopy in the visible region from 400 to $800 \mathrm{~nm}$ (Figure S2). At low NP concentrations used in this study, this low background absorption does not interfere with visual observation of color change from chromogenic substrates or quantitative spectroscopic measurements.

TMB is a commonly used peroxidase substrate. We next tested oxidation of TMB by $\mathrm{Fe}_{3} \mathrm{O}_{4} \mathrm{NPs}$. TMB in the reduced state is colorless. DNA and $\mathrm{Fe}_{3} \mathrm{O}_{4}$ NPs alone do not oxidize TMB (Figure 1a 
and Figure S2). In the presence of unmodified $\mathrm{Fe}_{3} \mathrm{O}_{4} \mathrm{NPs}$, TMB was slowly oxidized by $\mathrm{H}_{2} \mathrm{O}_{2}$, producing a moderate blue colour after 15 min (Figure 1a). Interestingly, a strong blue color appeared when DNA was added to the reaction mixture. The change of absorbance at $652 \mathrm{~nm}$ is around 8-fold higher with DNA than that with only the unmodified $\mathrm{Fe}_{3} \mathrm{O}_{4}$ NPs (Figure 1b). Therefore, DNA has promoted the activity of $\mathrm{Fe}_{3} \mathrm{O}_{4} \mathrm{NPs}$ as a peroxidase. To test the generality of this observation, we then employed $\mathrm{Fe}_{2} \mathrm{O}_{3} \mathrm{NPs}$. $\mathrm{Fe}_{2} \mathrm{O}_{3}$ was reported to have a lower peroxidase activity (likely due to the lack of $\mathrm{Fe}^{2+}$ on the surface), ${ }^{6}$ and DNA also induced faster colour change (Figure S3). This significant rate enhancement has prompted us to conduct more research for a better understanding.


Figure 1. (a) Accelerated oxidation of TMB using the $C_{30}$ DNAmodified $\mathrm{Fe}_{3} \mathrm{O}_{4} \mathrm{NPs}$ as a peroxidase mimic. The photographs of the reaction substrate and product are shown. (b) UV-vis spectra of the reaction products with and without DNA after 15 min reaction.

Our previous work has indicated that DNA is tightly adsorbed by $\mathrm{Fe}_{3} \mathrm{O}_{4}$ NPs mainly via the phosphate backbone of DNA at neutral $\mathrm{pH} .{ }^{34}$ From $\zeta$-potential measurement, $\mathrm{Fe}_{3} \mathrm{O}_{4}$ NPs carry a negative charge at $\mathrm{pH} 7.6$ and a positively charge at pH 4 (Table S2). Our TMB oxidation experiment was carried out at $\mathrm{pH} 4$, and thus electrostatic interaction might also contribute to DNA adsorption. To evaluate the effect of DNA on the peroxidase property of $\mathrm{Fe}_{3} \mathrm{O}_{4} \mathrm{NPs}$, we first tested the kinetics of TMB oxidation as a function of DNA sequence. $\mathrm{Fe}_{3} \mathrm{O}_{4}$ NPs were incubated with 15-mer homo DNAs $\left(A_{15}, T_{15}, C_{15}\right.$, $\mathrm{G}_{15}$ ) at $\mathrm{pH} 4$ (acetate buffer, $10 \mathrm{mM}$ ) for $10 \mathrm{~min}$, followed by adding the substrate TMB. In the absence of $\mathrm{H}_{2} \mathrm{O}_{2}$, oxidation of TMB was slow and the added DNA did not alter the reaction (Figure S2). After adding $\mathrm{H}_{2} \mathrm{O}_{2}$, the reaction showed a DNA sequence dependent kinetics (Figure 2a). The order of reaction kinetics is: $C>G>T>A>$ No DNA. The initial rate of the $\mathrm{C}_{15}-\mathrm{Fe}_{3} \mathrm{O}_{4}$ NP conjugate is 9 times faster than that of unmodified $\mathrm{Fe}_{3} \mathrm{O}_{4} \mathrm{NPs}$, showing a significant enhancement effect. While we reported the major binding between DNA and $\mathrm{Fe}_{3} \mathrm{O}_{4}$ NPs are from the phosphate backbone, the secondary structure of homo DNAs may cause different interactions. $C_{15}$ was also found to be the most effective probe used for arsenate detection. ${ }^{34}$ The $\mathrm{pK}_{\mathrm{a}}$ of cytosine is 4.5 , and a large fraction of the base at $\mathrm{pH} 4$ is protonated, which may assist charge neutralization on the particle surface and reduce repulsion among DNA, allowing the packing of more DNA and accelerate the oxidation activity.

Next, we tested the effect of DNA length on the rate enhancement. By fixing the total concentration of nucleosides, we used poly $C_{n}(n=5,10,15$, and 30$)$ to modify $\mathrm{Fe}_{3} \mathrm{O}_{4} \mathrm{NPs}$ (e.g. the concentration of $C_{5}$ is six times higher than that of $C_{30}$ ). The initial rate exhibits a DNA length-dependent increase (Figure $2 b$ ). Poly $C_{30}$, the longest DNA tested here, shows the largest enhancement, even though its molar concentration is the lowest. Longer DNAs have higher affinity with the $\mathrm{Fe}_{3} \mathrm{O}_{4} \mathrm{NPs}$ due to the presence of more binding sites (e.g. polyvalent binding effect). This experiment strongly indicates that DNA adsorption affinity is crucial for activity enhancement. The fact that longer DNA provided higher activity suggests that the activity enhancement is from surface bound DNA.

We further examined the effect of DNA concentration. As shown in Figure 2c, higher DNA concentration induced faster TMB oxidation. When the concentration is higher than $500 \mathrm{nM}$, the enhancement is less significant, likely due to surface saturation (Figure S4). This experiment also indicates that it is the surface adsorbed DNA instead of free DNA in this system to increase the peroxidase activity of $\mathrm{Fe}_{3} \mathrm{O}_{4} \mathrm{NPs}$.

Since the peroxidase activity of $\mathrm{Fe}_{3} \mathrm{O}_{4} \mathrm{NPs}$ is $\mathrm{pH}$-dependent ${ }^{6}$ and $\mathrm{pH}$ may affect DNA adsorption, the effect of $\mathrm{pH}$ on the TMB oxidation was also tested. For the free $\mathrm{Fe}_{3} \mathrm{O}_{4} \mathrm{NPs}$ (green bars, Figure $2 \mathrm{~d}$ ), the reaction is more effective at lower $\mathrm{pH}$ (e.g. $\mathrm{pH}$ 4) as reported in the literature. The presence of DNA does not alter the $\mathrm{pH}$-dependent activity trend, but has enhanced the rate at each $\mathrm{pH}$. It is interesting to note that at $\mathrm{pH} 6$, the color change of TMB with DNA modified NPs is comparable to that at $\mathrm{pH} 4$ with the unmodified $\mathrm{Fe}_{3} \mathrm{O}_{4}$ NPs. Attaching DNA can expand the application of $\mathrm{Fe}_{3} \mathrm{O}_{4} \mathrm{NPs}$ over a broader $\mathrm{pH}$ range. The kinetic data of these reactions are shown in Figure S5.
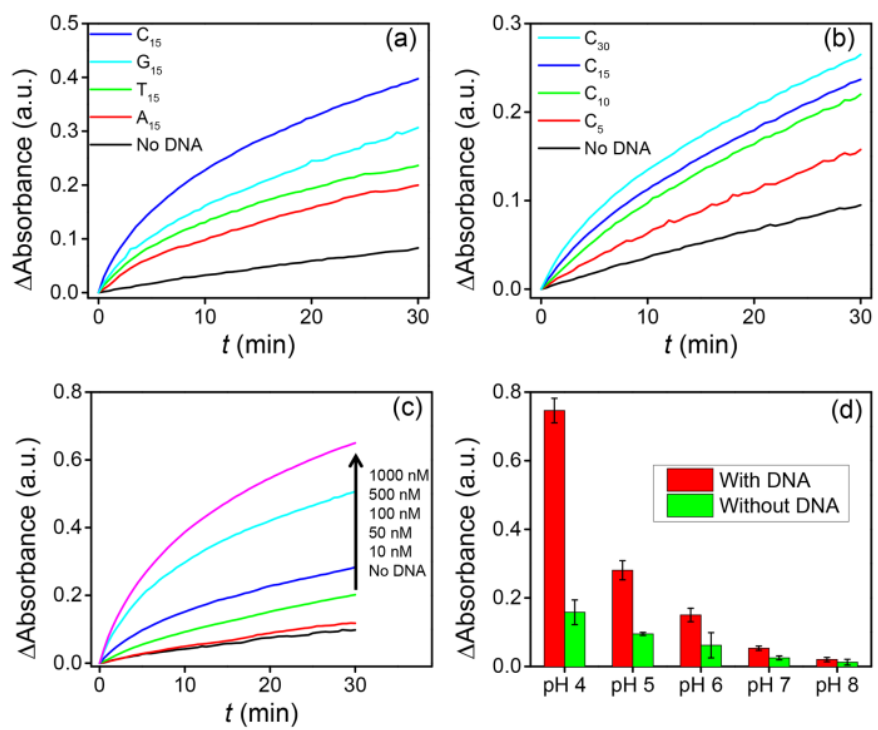

Figure 2. Effects of DNA (a) sequence, (b) length, (c) concentration on the kinetics of TMB oxidation catalysed by DNA modified $\mathrm{Fe}_{3} \mathrm{O}_{4}$ NPs. (d) The variation of absorbance at $652 \mathrm{~nm}$ as a function of $\mathrm{pH}$ values in the presence and absence of DNA. The error bars represent the standard deviation from three measurements.

Using polymer coatings to modulate nanozymes activity was also reported in a few other systems. ${ }^{14}$ In those examples, electrostatic interaction between $\mathrm{Fe}_{3} \mathrm{O}_{4} \mathrm{NPs}$ and the substrates (TMB and ABTS) was found to be important for the enzyme activity. If TMB (positively charged) was used as a substrate, more negatively charged particles showed higher $k_{\text {cat }}$ values. ${ }^{14}$ In another example, 
DNA from PCR products was reported to inhibit ophenylenediamine oxidation, as the electrostatic interaction between the positively charged substrate and the negatively charged $\mathrm{Fe}_{3} \mathrm{O}_{4} \mathrm{NP}$ surface is blocked by free DNA in solution and on particle surface. ${ }^{36}$ To understand the mechanism here, we first studied whether $\mathrm{H}_{2} \mathrm{O}_{2}$ and TMB can compete with DNA adsorption. We recently reported that $\mathrm{H}_{2} \mathrm{O}_{2}$ can efficiently displace DNA adsorbed by $\mathrm{CeO}_{2} \mathrm{NPs}$ due to the strong affinity between $\mathrm{H}_{2} \mathrm{O}_{2}$ and $\mathrm{CeO}_{2} \cdot{ }^{37}$ However, $\mathrm{H}_{2} \mathrm{O}_{2}$ only inhibited DNA adsorption by $\mathrm{Fe}_{3} \mathrm{O}_{4} \mathrm{NPS}$ at a very high concentration $(1 \mathrm{M})$ and no adsorption inhibition was observed at our experimental conditions (Figure 3a). TMB did not block and even slightly facilitated DNA adsorption onto $\mathrm{Fe}_{3} \mathrm{O}_{4} \mathrm{NPs}$ (Figure 3b). Second, we examined the integrity of DNA by gel electrophoresis. One concern is that DNA might be degraded in the presence of $\mathrm{H}_{2} \mathrm{O}_{2}$ and iron species (e.g. via the Fenton chemistry). The control group $\left(\mathrm{Fe}^{2+} / \mathrm{H}_{2} \mathrm{O}_{2}\right.$, lane 6 , Figure $3 \mathrm{c}$ ) indeed shows that the fluorophore tag on DNA (6-carboxyfluorescein, FAM) might be damaged due to generated hydroxyl free radicals indicated by the weak fluorescence intensity. However, DNA on the $\mathrm{Fe}_{3} \mathrm{O}_{4} \mathrm{NPs}$ surface was not cleaved and the fluorophore was not damaged at our experimental conditions (lane 5, Figure 3c). Combined with fluorescence-based results, DNA remained intact on the surface during and after the peroxidase reaction.
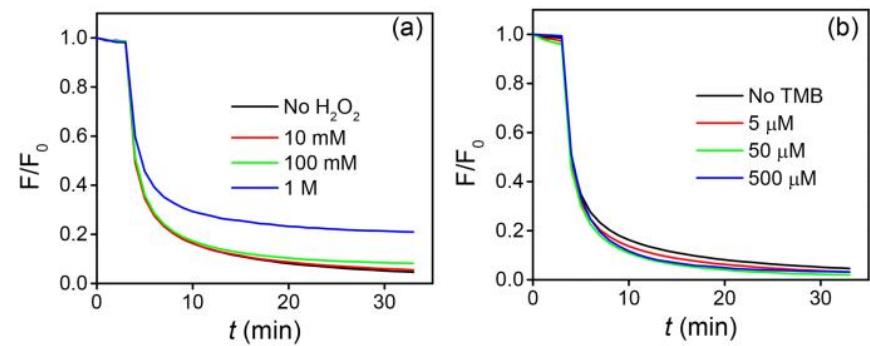

(c)

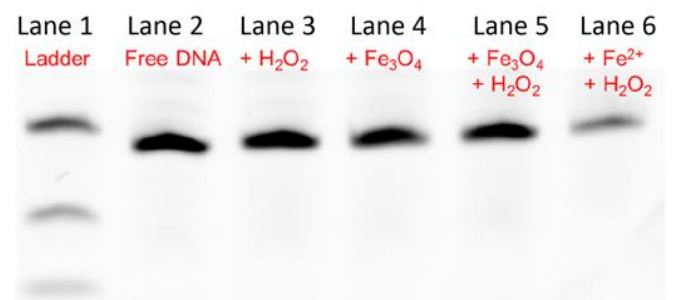

Figure 3. Kinetics of Alexa-DNA (50 nM) adsorption onto $\mathrm{Fe}_{3} \mathrm{O}_{4} \mathrm{NPs}$ $(25 \mu \mathrm{g} / \mathrm{mL})$ at $\mathrm{pH} 4$ (acetate buffer, $10 \mathrm{mM}$ ) in the presence of varying concentrations of (a) $\mathrm{H}_{2} \mathrm{O}_{2}$ and (b) TMB. The lack of obvious kinetic changes indicate that $\mathrm{H}_{2} \mathrm{O}_{2}$ and $T M B$ do not inhibit DNA adsorption. (c) Gel image of DNA- $\mathrm{Fe}_{3} \mathrm{O}_{4}$ treated with $\mathrm{H}_{2} \mathrm{O}_{2}$. Lane 1 is a DNA ladder with FAM-A,$F A M-A_{15}$ and $F A M-A_{30}$. Lane 2 is an untreated FAM-labeled 24 mer DNA. Lane 3-6 are the FAM DNA treated with various chemicals as indicated in the lanes. Acetate

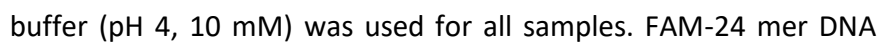
$(200 \mathrm{nM})$ was incubated with $\mathrm{Fe}_{3} \mathrm{O}_{4} \mathrm{NPs}(25 \mu \mathrm{g} / \mathrm{mL})$ or $\mathrm{Fe}^{2+}(50 \mu \mathrm{M})$ and $\mathrm{H}_{2} \mathrm{O}_{2}(10 \mathrm{mM})$ was added if necessary.

One possibility is that DNA facilitates the adsorption of TMB by $\mathrm{Fe}_{3} \mathrm{O}_{4}$ NPs. With two amino groups, the nonoxidized TMB has a $\mathrm{p} K_{\mathrm{a}}$ of $\sim 4.2$ and is partially positive charged at $\mathrm{pH} 4$ (Figure $4 \mathrm{~b}$ ). This may explain its affinity for DNA. If this hypothesis is true, the activity of $\mathrm{Fe}_{3} \mathrm{O}_{4} \mathrm{NPs}$ should decrease when a negatively charged substrate is used. To test this hypothesis, we then employed another peroxidase substrate, ABTS. ABTS is negative charged due to the dual sulfate anions (Figure $4 \mathrm{~b}$ ). As shown in Figure $4 \mathrm{a}$, after adding $\mathrm{H}_{2} \mathrm{O}_{2}(10 \mathrm{~min})$, ABTS was oxidized by the unmodified $\mathrm{Fe}_{3} \mathrm{O}_{4}$ NPs but not by the DNA-modified $\mathrm{Fe}_{3} \mathrm{O}_{4}$ NPs. DNA modification alters the surface charge of $\mathrm{Fe}_{3} \mathrm{O}_{4} \mathrm{NPs}$ from positive to negative (Table S2). The charge repulsion between ABTS and DNA surface inhibits the oxidation reaction. To further prove the charge repulsion mechanism, we monitored the oxidation of ABTS at different ionic strengths. In the absence of DNA, increasing $\mathrm{NaCl}$ concentration slightly inhibited TMB oxidation. In the presence of DNA, we found that the enzymatic performance was gradually recovered by increasing $\mathrm{NaCl}$ concentration to screen charge repulsion and the activity is even higher than unmodified $\mathrm{Fe}_{3} \mathrm{O}_{4} \mathrm{NPS}$ without additional $\mathrm{NaCl}$ (Figure 4c,d).
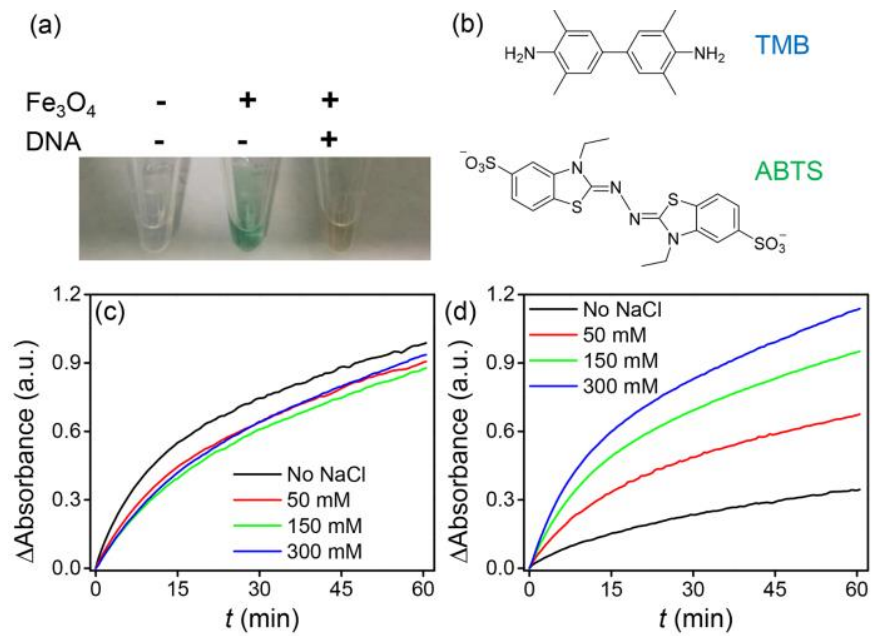

Figure 4. Oxidation of $A B T S(1 \mathrm{mM})$ in the presence of $\mathrm{Fe}_{3} \mathrm{O}_{4} \mathrm{NPs}$ $(50 \mu \mathrm{g} / \mathrm{mL})$ at $\mathrm{pH}$ 4. (a) A photograph showing oxidation of ABTS producing a green colour. The reaction is inhibited by DNA modification. (b) Chemical structures of TMB and ABTS. Kinetics of ABTS oxidation at various $\mathrm{NaCl}$ concentrations catalysed by (c) bare $\mathrm{Fe}_{3} \mathrm{O}_{4}$ NPs and (d) DNA-capped $\mathrm{Fe}_{3} \mathrm{O}_{4}$ NPs, respectively. The absorbance at $420 \mathrm{~nm}$ was monitored.

Aside from the negatively charged backbone, DNA can also provide hydrogen bonding, $\pi-\pi$ interactions via DNA bases. To test if DNA bases are involved in substrate binding, we compared DNA with other negatively charged polymers for coating $\mathrm{Fe}_{3} \mathrm{O}_{4}$ NPs. Polyacrylic acid (PAA) and polystyrene sulfonate (PSS) were respectively used to modify $\mathrm{Fe}_{3} \mathrm{O}_{4}$ NPs. The surface charge alternation at $\mathrm{pH} 4$ was confirmed by $\zeta$-potential measurement and all modified $\mathrm{Fe}_{3} \mathrm{O}_{4} \mathrm{NPs}$ exhibit similar negative charge values (Table S2). Compared to unmodified $\mathrm{Fe}_{3} \mathrm{O}_{4}$ NPs, negatively charged NPs all enhanced the activity and DNA modification provides the highest enhancement, followed by PSS and PAA (Figure 5a). DNA-modified $\mathrm{Fe}_{2} \mathrm{O}_{3}$ NPS also exhibited higher activity than PSS modified ones. (Figure S3b). To further emphasize the importance of DNA bases, we compared $\mathrm{Fe}_{3} \mathrm{O}_{4}$ NPs modified by phosphate, guanosine monophosphate (GMP), and $\mathrm{G}_{15}$ (Figure 5b). Phosphate also changes the surface charge of $\mathrm{Fe}_{3} \mathrm{O}_{4} \mathrm{NPs}$ to be negative (Table S2); however, the activity increase is minimal. As expected, GMPmodified $\mathrm{Fe}_{3} \mathrm{O}_{4} \mathrm{NPs}$ facilitate TMB oxidation, confirming the role the 
DNA bases. The further increased activity by $\mathrm{G}_{15}$ functionalization is consistent with our observation that the enhancement is DNA length-dependent (Figure 2b). We propose that DNA bases also facilitate the substrate binding via hydrogen bonding with the amino groups of $\mathrm{TMB}$, and/or the nucleobase interacting with the benzene rings of $\mathrm{TMB}$ via $\pi-\pi$ stacking.
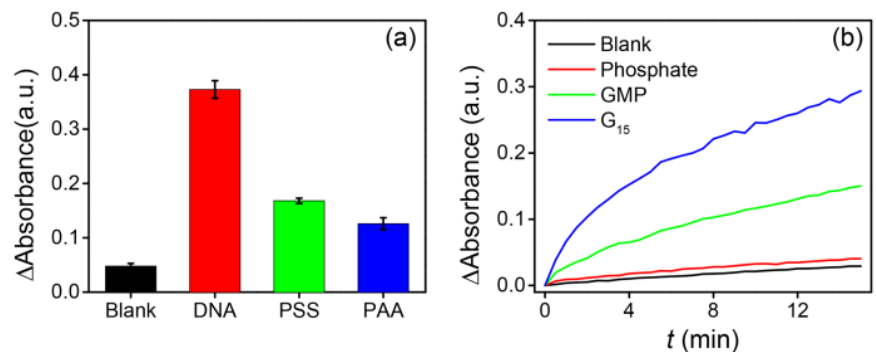

Figure 5. Comparison of the peroxidase activity of $\mathrm{DNA}-\mathrm{Fe}_{3} \mathrm{O}_{4} \mathrm{NPS}$ with (a) various negatively charged polymers coated $\mathrm{Fe}_{3} \mathrm{O}_{4} \mathrm{NPs}$ and (b) phosphate and GMP modified $\mathrm{Fe}_{3} \mathrm{O}_{4}$ NPs. The error bars represent standard deviation from three independent measurements.

Now that we have changed the polymer coating and substrate, we finally also tested a different type of $\mathrm{NP}, \mathrm{CeO}_{2}$. We previously reported that the oxidase activity of $\mathrm{CeO}_{2}$ is inhibited by adsorbed DNA for oxidation of TMB. ${ }^{38}$ However, the peroxidase activity of $\mathrm{CeO}_{2}$ is actually enhanced by DNA modification (Figure S6). This might be attributed to that TMB needs to be directly adsorbed by $\mathrm{CeO}_{2}$ to be oxidized in the absence of $\mathrm{H}_{2} \mathrm{O}_{2}$ (i.e. $\mathrm{CeO}_{2}$ surface works as an oxidizing agent). ${ }^{39} \mathrm{However}$, in the presence of $\mathrm{H}_{2} \mathrm{O}_{2}, \mathrm{CeO}_{2}$ can mediate the oxidation at a distance from the surface. As an oxidase, the TMB substrate need to get onto the particle surface since the oxidizing agent is the particle surface. As a peroxidase, the actual oxidizing agent is derived from $\mathrm{H}_{2} \mathrm{O}_{2}$ (e.g. reactive oxygen species), which can diffuse near the particle surface. The activity of $\mathrm{Fe}_{3} \mathrm{O}_{4}$ NPs we studied here is the peroxidase activity. In this case, the surface is likely to react with $\mathrm{H}_{2} \mathrm{O}_{2}$ and then the reactive oxygen species produced in this process is used to oxidize TMB. $\mathrm{H}_{2} \mathrm{O}_{2}$ is a much smaller molecule and DNA does not block its access to the $\mathrm{Fe}_{3} \mathrm{O}_{4} \mathrm{NPs}$.

In summary, we observed a significant rate enhancement brought by DNA for the peroxidase activity of $\mathrm{Fe}_{3} \mathrm{O}_{4} \mathrm{NPs}$ for TMB oxidation. Such a rate enhancement will make such a nanozyme a better material for biosensor development and catalysis. Starting from this observation, we investigated the effect of DNA adsorption on enhancing the peroxidase-like activity of $\mathrm{Fe}_{3} \mathrm{O}_{4} \mathrm{NPs}$. DNA/Fe $\mathrm{O}_{3}$ forms a stable hybrid material, and neither $\mathrm{H}_{2} \mathrm{O}_{2}$ nor TMB can displace DNA from the particle surface under our experimental conditions. Among all the tested anionic polymers, DNA affords the highest rate enhancement. This is attributed to both electrostatic attraction and aromatic stacking with the substrate TMB. The hypothesis is further supported by using a negative charged substrate $\mathrm{ABTS}$ and with $\mathrm{CeO}_{2} \mathrm{NPs}$. The insight from this work will be useful for further rational improving nanozyme activity via surface modification.

Funding for this work is from the University of Waterloo, the Canadian Foundation for Innovation, the NSERC of Canada, and the
Early Researcher Award from the Ontario Ministry of Research and Innovation.

\section{Notes and references}

1. Y. Lin, J. Ren and X. Qu, Acc. Chem. Res., 2014, 47, 10971105.

2. H. Wei and E. Wang, Chem. Soc. Rev., 2013, 42, 60606093.

3. I. Celardo, J. Z. Pedersen, E. Traversa and L. Ghibelli, Nanoscale, 2011, 3, 1411-1420.

4. M. Comotti, C. Della Pina, R. Matarrese and M. Rossi, Angew. Chem. Int. Ed., 2004, 43, 5812-5815.

5. W. Luo, C. Zhu, S. Su, D. Li, Y. He, Q. Huang and C. Fan, ACS Nano, 2010, 4, 7451-7458.

6. L. Gao, J. Zhuang, L. Nie, J. Zhang, Y. Zhang, N. Gu, T. Wang, J. Feng, D. Yang, S. Perrett and X. Yan, Nat. Nanotechnol., 2007, 2, 577-583.

7. A. Asati, S. Santra, C. Kaittanis, S. Nath and J. M. Perez, Angew. Chem. Int. Ed., 2009, 48, 2308-2312.

8. J. Dong, L. Song, J.-J. Yin, W. He, Y. Wu, N. Gu and Y. Zhang, ACS Appl. Mater. Interfaces, 2014, 6, 1959-1970.

9. R. Ragg, F. Natalio, M. N. Tahir, H. Janssen, A. Kashyap, D. Strand, S. Strand and W. Tremel, ACS Nano, 2014, 8, 51825189.

10. Y. Song, K. Qu, C. Zhao, J. Ren and X. Qu, Adv. Mater., 2010, 22, 2206-2210.

11. Y. Song, X. Wang, C. Zhao, K. Qu, J. Ren and X. Qu, Chem. - Eur. J., 2010, 16, 3617-3621.

12. H. Wei and E. Wang, Anal. Chem., 2008, 80, 2250-2254.

13. Y.-I. Dong, H.-g. Zhang, Z. U. Rahman, L. Su, X.-j. Chen, J. Hu and X.-g. Chen, Nanoscale, 2012, 4, 3969-3976.

14. F. Yu, Y. Huang, A. J. Cole and V. C. Yang, Biomaterials, 2009, 30, 4716-4722.

15. X.-Q. Zhang, S.-W. Gong, Y. Zhang, T. Yang, C.-Y. Wang and N. Gu, J. Mater. Chem., 2010, 20, 5110-5116.

16. S. Liu, F. Lu, R. Xing and J.-J. Zhu, Chem. - Eur. J., 2011, 17, 620-625.

17. K. N. Chaudhari, N. K. Chaudhari and J.-S. Yu, Catal. Sci. Technol., 2012, 2, 119-124.

18. J. I. Cutler, E. Auyeung and C. A. Mirkin, J. Am. Chem. Soc., 2012, 134, 1376-1391.

19. K. Saha, S. S. Agasti, C. Kim, X. Li and V. M. Rotello, Chem. Rev., 2012, 112, 2739-2779.

$20 . \quad$ O. I. Wilner and I. Willner, Chem. Rev., 2012, 112, 25282556.

21. V. Tjong, L. Tang, S. Zauscher and A. Chilkoti, Chem. Soc. Rev., 2014, 43, 1612-1626.

22. C. A. Mirkin, R. L. Letsinger, R. C. Mucic and J. J. Storhoff, Nature, 1996, 382, 607-609.

23. A. P. Alivisatos, K. P. Johnsson, X. Peng, T. E. Wilson, C. J. Loweth, M. P. Bruchez and P. G. Schultz, Nature, 1996, 382, 609-611.

24. J. J. Storhoff and C. A. Mirkin, Chem. Rev., 1999, 99, 18491862.

25. Y. Lu and J. Liu, Acc. Chem. Res., 2007, 40, 315-323.

26. E. Katz and I. Willner, Angew. Chem. Int. Ed., 2004, 43, 6042-6108.

27. C.-H. Lu, H.-H. Yang, C.-L. Zhu, X. Chen and G.-N. Chen, Angew. Chem. Int. Ed., 2009, 48, 4785-4787. 
28. H. Wang, R. Yang, L. Yang and W. Tan, ACS Nano, 2009, 3, 2451-2460.

29. J. Liu, Z. Cao and Y. Lu, Chem. Rev., 2009, 109, 1948-1998.

30. N. L. Rosi and C. A. Mirkin, Chem. Rev., 2005, 105, 15471562.

31. D. A. Giljohann, D. S. Seferos, W. L. Daniel, M. D. Massich, P. C. Patel and C. A. Mirkin, Angew. Chem. Int. Ed., 2010, 49, 3280-3294.

32. D. Li, S. Song and C. Fan, Acc. Chem. Res., 2010, 43, 631641.

33. W. Tan, M. J. Donovan and J. Jiang, Chem. Rev., 2013, 113, 2842-2862.

34. B. Liu and J. Liu, Chem. Commun., 2014, 50, 8568-8570.

35. C. Song, G.-Y. Wang and D.-M. Kong, Biosens. Bioelectron., 2015, 68, 239-244.

36. K. S. Park, M. I. Kim, D.-Y. Cho and H. G. Park, Small, 2011, 7, 1521-1525.

37. B. Liu, Z. Sun, P.-J. J. Huang and J. Liu, J. Am. Chem. Soc., 2015, 137, 1290-1295.

38. R. Pautler, E. Y. Kelly, P.-J. J. Huang, J. Cao, B. Liu and J. Liu, ACS Appl. Mater. Interfaces, 2013, 5, 6820-6825.

39. Y. Peng, X. Chen, G. Yi and Z. Gao, Chem. Commun., 2011, 47, 2916-2918. 